\title{
Helmet use behavior and its relation to head injury of road traffic accident in Indonesia (Basic Health Research, 2018)
}

DOI: https://doi.org/10.22435/hsji.v12i1.4655

Lusianawaty Tana ${ }^{1}$, Delima ${ }^{1}$, Nunik Kusumawardani ${ }^{2}$, Lely Indrawati ${ }^{2}$

${ }^{1}$ Center for Research and Development of Health Resources and Services, National Institute Of Health Research and Development, Ministry Of Health, Republic of Indonesia

${ }^{2}$ Center for Research and Development of Public Health Efforts, National Institute of Health Research and Development, Ministry Of Health, Republic Of Indonesia

Corresponding author: Lusianawaty Tana

Email: lusianawaty@yahoo.com

Received: March 12, 2021; Revised: May 4, 2021; Accepted: June 14, 2021.

\begin{abstract}
Background: Nationally, the prevalence of injuries tends to increase from $7.5 \%$ in $2007,8.2 \%$ in 2013 , and $9.2 \%$ in 2018. The main cause of injuries is motorcycle accidents (40.6\%), which most occur on the highway (42.8\%). This is a further analysis of Indonesia Basic Health Research (Riskesdas) 2018 data, to assess the role of sociodemography on helmet use behavior and head injuries due to traffic accident.
\end{abstract}

Methods: The 2018 Basic Health Research was a cross-sectional research, based on data from individuals aged 5 years old and above, who analyzed with helmet use behavior and the incidence of head injuries due to traffic accident as dependent variables. The independent variables consist of sociodemographic characteristics, the role of individual in accident, and the impact of the accident. The data were analyzed by bivariate and multivariate, and taking into account the complex sample in 5\% confidence level.

Results: The results showed that $44.4 \%$ from 19122 individuals aged five years old and above had good behavior in using helmets. The determinants of helmet use behavior were age, gender, education, occupation, economic status, location and area of residence (adjusted OR 1.15 - 4.5; $\mathrm{p} \leq 0.02$ ). The result from $14.1 \%$ of respondents who had a head injuries caused by traffic accidents. The risk of head injuries due to traffic accidents was 1.17 times $(95 \%$ CI $1.02-1.35 ; p 0.03)$ in the unhelmeted group compared to the helmeted group.

Conclusion: Helmet use behavior is connected with the reduction of head injuries due to traffic accidents. Counseling and monitoring of helmet use is need to be improved, especially for the youth category. (Health Science Journal of Indonesia 2021;12(1):55-65)

Keywords: head injury, traffic accident, helmet use

\begin{abstract}
Abstrak
Latar belakang: Secara nasional, prevalensi cedera cenderung meningkat dari 7,5\% pada tahun 2007, $8,2 \%$ pada 2013, dan 9,2\% pada 2018. Penyebab utama dari cedera adalah kecelakaan bermotor (40,6 $\%)$, dan kebanyakan terjadi di jalan raya (42,8\%). Ini merupakan analisis lanjut data Riset Kesehatan Dasar (Riskesdas) 2018 untuk menilai peran sosiodemografi terhadap perilaku penggunaan helm dan hubungan perilaku penggunaan helm dengan cedera kepala akibat kecelakaan lalu lintas.
\end{abstract}

Metode: Riskesdas 2018 adalah riset potong lintang. Data individu umur 5 tahun ke atas dianalisis dengan perilaku penggunaan helm dan kejadian cedera kepala akibat kecelakaan lalu lintas sebagai variabel terikat. Variabel bebas terdiri dari karakteristik sosiodemografi, peran individu dalam kecelakaan, dan dampak kecelakaan. Data dianalisis secara bivariat dan multivariat dengan memperhitungkan complex sample dan $5 \%$ tingkat kepercayaan.

Hasil: Hasil menunjukkan bahwa 44,4\% dari 19.122 individu umur 5 tahun ke atas mempunyai perilaku yang baik dalam menggunakan helm. Determinan perilaku penggunaan helm adalah umur, jenis kelamin, pendidikan, pekerjaan, status ekonomi, lokasi dan area tempat tinggal (adjusted OR 1,15-4,5; $p \leq 0,02$ ). Sejumlah 14,1\% individu mengalami cedera kepala akibat kecelakaan lalu lintas. Risiko cedera kepala pada individu yang tidak menggunakan helm sebesar 1,17 kali (95\% CI 1,02-1,35; p 0,03) dibandingkan dengan individu yang menggunakan helm.--

Kesimpulan: Perilaku penggunaan helm berhubungan dengan penurunan cedera kepala akibat kecelakaan lalu lintas. Penyuluhan dan pemantauan penggunaan helm perlu ditingkatkan terutama pada kelompok remaja. (Health Science Journal of Indonesia 2021;12(1):56-65) 
The national injury prevalence according to Indonesia Basic Health Research tends to increase increase from $7.5 \%$ in 2007 to $8.2 \%$ in 2013 , and $9.2 \%$ in 2018 while the prevalence of traffic accidents was $2.2 \%$ in 2018. ${ }^{1-4}$ The 2018 Basic Health Research data showed the highest prevalence of injury was in the younger age group with $12.2 \%$ at the age of 15-24 years and $12.1 \%$ at the age of 5-14 years. The proportion of road injuries according to all types of injuries was $31.4 \% .^{3}$

Age and gender are known to be the main determinants of injury in productive age..$^{5}$ The type of injury, cause of injury, and injured body parts contribute to the severity of the injury which is categorized based on the length of hospital stay. Injuries with longer hospital stays are head injuries, fractures, and eye injuries. ${ }^{6}$

The Central Bureau of Statistics reported an increase in the number of all types of motorized vehicles in the four years from 2009 to 2012 based on data from the Indonesian National Police Department. Motorcycles are the highest in number, which is an increase of $13.11 \%{ }^{7}$. Based on gender category, men is more often to injured at work, not only because the men is dominant to spend their time on the road than women, but also because of unsafe behavior or actions on the road. Deadly case from traffic accident injuries was significantly three times higher for men than women. ${ }^{8,9}$ Human-caused factors is identified as the biggest factors for traffic injuries. ${ }^{10}$

In 2008, injuries were estimated to be the cause of death in 2.9 million people, counting for $10 \%$ of all deaths in the Asia Pacific region. This number is more than half of the deaths due to injuries in the world. The magnitude of injury in the Asia Pacific varies between countries. It is related to the cause of injury, age, gender, and income level. ${ }^{11}$

Study on 2006 - 2016 about traffic accident deaths in Iran showed that $19.5 \%$ of traffic accident deaths occurred among motorcyclists with an average age of $32.3 \pm 18.5$ years. $^{12}$ The main mechanism of the accident is relate between motorcycles and other vehicles, which mostly happen with cars $(34.8 \%)$. The traffic accidents that occur in cities, is contribute for $40.7 \%$ of motorcyclists' deaths, with head injury as the main causes of death.

Systematic review of 53 studies concluded that despite differences in research methods, there were consistent results especially in mortality and head injury. The motorcycle helmets use can reduce the risk of death and head injury for about $72 \% .{ }^{13}$ In Thailand, if people who non-helmet users is started to wore a helmet, it could prevent $40 \%$ of road traffic potential death. ${ }^{14}$

However, many studies reported a different behavior about the helmet use. For example, the majority of adult riders and pillions wore a helmet $(93.4 \%$ and $85.8 \%$ ) in Malaysia. ${ }^{15}$ Moreover, a study in Thailand's urban arterial road reported there are only $67 \%$ from motorcyclists who wearing the helmet. ${ }^{16}$ In Mysuru city, India, only 19.5 per 100 person minute of observation among motorcyclists used effective helmets. ${ }^{17}$

Several causes is contributed to the non-helmet use, such as age, gender, geography, and behavior. ${ }^{18}$ Teens and children, women, rural areas, and alcohol consumption is also connected with the non helmet use. ${ }^{18}$ Other studies have shown that properly wearing a helmet with buttons is more efective at protecting motorcyclists than any type of helmet. ${ }^{19}$ People who use helmets in motorcycle accidents have a less intracranial injury. ${ }^{20}$

The 2018 Basic Health Research is more detailed on injury data than the 2013 Basic Health Research. There is data on injuries due to traffic accidents, accident sites, and helmet use behavior. To find out the relationship between helmet use behavior and head injuries in road traffic accidents in Indonesia, it is necessary to conduct an assessment. Unfortunately, there is no data about the motorcyclists driver license or have a training for safety driving before their getting a driver license.

Further analysis of the 2018 Basic Health Research data was carried out to assess the relationship, between sociodemographic factors with helmet use behavior and helmet use behavior with head injuries in road traffic accidents in Indonesia. This analysis is expected to be useful for policy makers, to reduce traffic accident injuries in Indonesia.

\section{METHODS}

This was a further analysis of Basic Health Research (Riskesdas) 2018 data which was collected in a cross-sectional design survey in 34 provinces of Indonesia., ${ }^{3,4}{ }^{21}$ The study about the population according to Indonesian residents, who selected sample residents has already interviewed at Riskesdas 2018. The inclusion is the criteria were aged 5 years 
old and above and the exclusion criteria were people with incomplete or extreme data.

Based on data collected from Riskesdas 2018 household questionnaire (RKD.18.RT), Riskesdas 2018 individual questionnaire (RKD-18.IND), and the 2018 National Socioeconomic Survey (Susenas) questionnaire, to get the contributing factors of the helmet use behavior, we analyzed helmet use behavior as dependent variables and individual characteristics (age, gender, education, main occupation), location of residence (urban and rural areas), area of residence, and the socio-economic status, respondent's role at the accident, and the impact of the injury as independent variables. The education was divided into 3 groups: low education for junior high school graduates or below, intermediate for senior high school graduates, and high for university/academy graduates. The occupation based on the main job risk was divided into 7 groups: not working, study, entrepreneur, employee (government and nongovernment employee), laborers (laborers/drivers/ household helpers), farmers/farm laborers, and others (including fishermen). The socio-economic status was divided into 2 groups based on quintile, which are high (quintile 5) and low (quintile 1-4).

Traffic accident injury was categorized for head injury and non-head injury. Helmet use behavior was defined as good if the respondent is always wears a helmet while riding motorcycle, and not good or poor if it occasionally or even never wear helmets. The area of residence or region was divided into the Sumatera area, the Eastern Region of Indonesia (Kalimantan, Sulawesi, Nusa Tenggara, Maluku and Papua), and the Java-Bali area. The respondent's role at an accident was divided into as a motorcyclist or not, also as a passenger of motorcycle or not. The worst possibilites from impact of injury could be a loss of limbs, disability or defective distinguished from whether if there was a loss of senses injuries or not, even a discomfort.

The analyzed data in a complex sample method, presented univariate, bivariate and multivariate with a significance level of 0.05 and $95 \%$ confidence of interval.

\section{RESULTS}

The total number of respondents included in the analyses was 19122, while the characteristic of respondents and injuries were shown in table 1.
The highest proportion of respondents was $15-24$ years old group (38.5\%), followed by $25-34$ years old $(20.7 \%)$, and the lowest was 55 years old and 5-14 years old (7\%, and $8.1 \%)$. The male was higher than the female respondent $(65.4 \%$ and $34.6 \%$ ), more than half of respondents were in low education (62.6\%), most respondents were of low socio-economic status $72.1 \%$. About $59 \%$ stayed in the Java-Bali region and $81 \%$ as a motorcyclist, only $20.7 \%$ as a passenger of the motorcycle. The uncomfortable permanent scars $14.3 \%$, but vision dysfunction only $0.5 \%$ and loss of limbs $0.6 \%$.

People aged $\geq 5$ years old who suffered head injuries due to road traffic accidents were $14.1 \%$. A total of $44.4 \%$ of people aged $\geq 5$ years old always worn a helmet when riding a motorcycle on road, but $55.6 \%$ of them only occasionally worn helmet or even never worn a helmet when riding motorcycle.

The composite of sociodemographic characteristics to helmet use behavior was shown in table 2 .

Determinants of helmet use behavior were age, gender, education, socio-economic status, main occupation, location of residence, and area of residence (Adjusted OR 1.15—5.43; $\mathrm{p} \leq 0.024$ ).

The respondent with good behavior of helmet use was low in the 5-14 years old group compared with others age group $(13.3 \%)$, where the male was higher than the female ( $46.1 \%$ and $41.2 \%)$, the high and intermediate group of education were higher than the low education group. More respondents with high socio-economic status had a good behavior of helmet use than the lower socio-economic status group (49.7\% and $38.6 \%)$.

Based on the occupation, respondents with the main job as a farmer or a farm laborer were the lowest percentage of good helmet use behavior. The respondent who lived in urban had better behavior of helmet use than who lived in rural, and respondent who lived in Sumatera region was the worst respondents from other regions.

Determinants of head injury caused by traffic accidents were shown in table 3 .

Determinants of head injury due to traffic accidents were helmet use behavior, residential area, respondent's role at the time of injury, the impact of injury (sensory dysfunction and permanent scars that interfere with comfort) with adjusted OR $1.1-3.5, \mathrm{p} \leq 0.05$. Age, education, and main occupation were confounding factors. 
Tabel 1. Proportion of respondent' characteristics, head injury, helmet use, activity during injury, and impact of injury in Indonesia

\begin{tabular}{|c|c|c|c|}
\hline Variables & Proportion (\%) & $95 \% \mathrm{CI}$ & Standard Error (\%) \\
\hline \multicolumn{4}{|l|}{ Age group (years) } \\
\hline - $\quad 55-90$ & 7.0 & $6.5-7.5$ & 0.25 \\
\hline - $45-54$ & 10.2 & $9.7-10.8$ & 0.30 \\
\hline - $\quad 35-44$ & 15.5 & $14.8-16.3$ & 0.39 \\
\hline - $25-34$ & 20.7 & $19.7-21.7$ & 0.49 \\
\hline - $15-24$ & 38.5 & $37.4-39.6$ & 0.54 \\
\hline - $5-14$ & 8.1 & $7.6-8.6$ & 0.26 \\
\hline \multicolumn{4}{|l|}{ Gender } \\
\hline - $\quad$ Male & 65.4 & $64.5-66.4$ & 0.50 \\
\hline - Female & 34.6 & $33.6-35.5$ & 0.50 \\
\hline \multicolumn{4}{|l|}{ Education } \\
\hline - High & 3.0 & $2.6-3.4$ & 0.20 \\
\hline - Intermediate & 34.4 & $33.4-35.5$ & 0.55 \\
\hline - Low & 62.6 & $61.5-63.6$ & 0.56 \\
\hline \multicolumn{4}{|l|}{ Socio-economic status } \\
\hline - High & 27.9 & $26.8-29.1$ & 0.59 \\
\hline - $\quad$ Low & 72.1 & $70.9-73.2$ & 0.59 \\
\hline \multicolumn{4}{|l|}{ Occupation (main job) } \\
\hline - Not working & 20.8 & $19.9-21.7$ & 0.45 \\
\hline - $\quad$ Study & 20.4 & $19.6-21.3$ & 0.42 \\
\hline - $\quad$ Entrepreneur & 15.0 & $14.2-15.8$ & 0.40 \\
\hline - Employee & 16.2 & $15.4-17.1$ & 0.43 \\
\hline - Laborer & 11.9 & $11.1-12.8$ & 0.42 \\
\hline - Others & 5.5 & $5.1-6.0$ & 0.24 \\
\hline - $\quad$ Farmers/farm laborers & 10.2 & $9.7-10.8$ & 0.27 \\
\hline \multicolumn{4}{|l|}{ Location of residence } \\
\hline - Urban & 58.3 & $57.5-59.1$ & 0.40 \\
\hline - $\quad$ Rural & 41.7 & $40.9-42.5$ & 0.40 \\
\hline \multicolumn{4}{|l|}{ Area of residence (region) } \\
\hline - $\quad$ Eastern of Indonesia & 23.0 & $22.4-23.6$ & 0.30 \\
\hline - Java- Bali & 59.0 & $58.2-59.8$ & 0.40 \\
\hline - $\quad$ Sumatera & 18.0 & $17.5-18.6$ & 0.28 \\
\hline \multicolumn{4}{|l|}{ Head injury of traffic accident } \\
\hline - Injured & 14.1 & $13.4-14.8$ & 0.35 \\
\hline - $\quad$ Not injured & 85.9 & $85.2-86.6$ & 0.35 \\
\hline \multicolumn{4}{|l|}{ Helmet use behavior } \\
\hline - $\quad$ Good & 44.4 & $43.3-45.5$ & 0.56 \\
\hline - $\quad$ Poor & 55.6 & $54.5-56.7$ & 0.56 \\
\hline \multicolumn{4}{|l|}{ Standard of helmet usage ${ }^{1}$} \\
\hline - Non-standard helmet & 0.5 & $0.3-0.6$ & 0.08 \\
\hline - Standard helmet but unbottoned & 6.8 & $6.2-7.4$ & 0.30 \\
\hline - Standard helmet and bottoned & 92.7 & $92.1-93.3$ & 0.31 \\
\hline \multicolumn{4}{|l|}{ Motorcyclist } \\
\hline - Yes & 81.0 & $80.1-81.8$ & 0.43 \\
\hline - $\quad$ No & 19.0 & $18.2-19.9$ & 0.43 \\
\hline \multicolumn{4}{|l|}{ Passenger of motorcycle } \\
\hline - $\quad$ Yes & 20.7 & $19.8-21.5$ & 0.40 \\
\hline - $\quad$ No & 79.3 & $78.5-80.2$ & 0.40 \\
\hline \multicolumn{4}{|l|}{ Vision disfunction } \\
\hline - $\quad$ Yes & 0.5 & $0.4-0.7$ & 0.07 \\
\hline - $\quad$ No & 99.5 & $99.3-99.6$ & 0.07 \\
\hline \multicolumn{4}{|l|}{ Loss of limbs } \\
\hline - $\quad$ Yes & 0.6 & $0.5-0.8$ & 0.08 \\
\hline - $\quad$ No & 99.4 & $99.2-99.5$ & 0.08 \\
\hline \multicolumn{4}{|l|}{ Uncomfortable permanent scars } \\
\hline - $\quad$ Yes & 14.3 & $13.6-15.1$ & 0.39 \\
\hline - $\quad$ No & 85.7 & $84.9-86.4$ & 0.39 \\
\hline
\end{tabular}


Table 2. Association of sociodemographic factors with helmet use behavior in Indonesia

\begin{tabular}{|c|c|c|c|}
\hline Sociodemographic Factors & $\begin{array}{c}\text { Good Behaviour of Helmet Use } \\
(\%)\end{array}$ & $\begin{array}{l}\text { Adjusted OR } \\
(95 \% \mathrm{CI})\end{array}$ & $\mathrm{p}$ value \\
\hline \multicolumn{4}{|l|}{ Age group (years) } \\
\hline - $\quad 55-90$ & 50.9 & $5.43(3.90-7.56)$ & 0.0001 \\
\hline - $\quad 45-54$ & 52.2 & $4.87(3.55-6.69)$ & 0.0001 \\
\hline - $\quad 35-44$ & 51.2 & $4.31(3.17-5.86)$ & 0.0001 \\
\hline - $25-34$ & 51.8 & $3.89(2.85-5.30)$ & 0.0001 \\
\hline - $\quad 15-24$ & 40.8 & $2.88(2.22-3.74)$ & 0.0001 \\
\hline - $5-14$ & 13.3 & 1 & \\
\hline \multicolumn{4}{|l|}{ Gender } \\
\hline - $\quad$ Male & 46.1 & $1.23(1.09-1.39)$ & 0.001 \\
\hline - Female & 41.2 & 1 & \\
\hline \multicolumn{4}{|l|}{ Education } \\
\hline - High & 66.2 & $2.47(1.77-3.44)$ & 0.0001 \\
\hline - Intermediate & 56.5 & $1.84(1.62-2.09)$ & 0.0001 \\
\hline - $\quad$ Low & 34.4 & 1 & \\
\hline \multicolumn{4}{|l|}{ Socio-economic status } \\
\hline - $\quad$ High & 49.7 & $1.15(1.02-1.29)$ & 0.02 \\
\hline - $\quad$ Low & 38.6 & 1 & \\
\hline \multicolumn{4}{|l|}{ Occupation (main job) } \\
\hline - $\quad$ Not working & 38.3 & $1.29(1.06-1.59)$ & 0.01 \\
\hline - $\quad$ Study & 33.5 & $1.67(1.33-2.10)$ & 0.0001 \\
\hline - Entrepreneur & 56.1 & $1.87(1.54-2.27)$ & 0.0001 \\
\hline - $\quad$ Employee & 65.6 & $2.18(1.72-2.76)$ & 0.0001 \\
\hline - Laborers & 45.3 & $1.45(1.16-1.81)$ & 0.001 \\
\hline - $\quad$ Others & 50.6 & $1.66(1.29-2.15)$ & 0.0001 \\
\hline - $\quad$ Farmers/farm laborers & 28.6 & 1 & \\
\hline \multicolumn{4}{|l|}{ Location of residence } \\
\hline - Urban & 54.6 & $2.19(1.95-2.45)$ & 0.0001 \\
\hline - $\quad$ Rural & 30.1 & 1 & \\
\hline \multicolumn{4}{|l|}{ Area of residence (region) } \\
\hline - $\quad$ Eastern of Indonesia & 42.7 & $1.25(1.10-1.42)$ & 0.001 \\
\hline - Java- Bali & 47.2 & $1.20(1.06-1.37)$ & 0.006 \\
\hline - $\quad$ Sumatera & 37.2 & 1 & \\
\hline
\end{tabular}


Tabel 3. Determinants of head injury caused by traffic accident in Indonesia

\begin{tabular}{|c|c|c|c|c|c|}
\hline Determinant & $\begin{array}{l}\text { Head Injury } \\
(\%)\end{array}$ & $\begin{array}{c}\text { OR } \\
(95 \% \mathrm{CI})\end{array}$ & $\mathrm{p}$ & $\begin{array}{c}\text { Adjusted OR } \\
(95 \% \mathrm{CI})\end{array}$ & $\mathrm{p}$ \\
\hline \multicolumn{6}{|l|}{ Age group (years) } \\
\hline - $\quad 5-14$ & 19.8 & $1.11(0.80-1.55)$ & 0.53 & $1.11(0.80-1.55)$ & 0.54 \\
\hline - $15-24$ & 13.4 & $1.16(0.92-1.47)$ & 0.21 & $1.16(0.92-1.47)$ & 0.21 \\
\hline - $\quad 35-44$ & 14.3 & $1.20(0.95-1.52)$ & 0.12 & $1.20(0.95-1.52)$ & 0.13 \\
\hline - $45-54$ & 15.4 & $1.30(1.00-1.67)$ & 0.05 & $1.29(1.00-1.67)$ & 0.05 \\
\hline - $\quad 55-90$ & 16.4 & $1.17(0.89-1.54)$ & 0.26 & $1.17(0.89-1.54)$ & 0.26 \\
\hline - $25-34$ & 11.7 & 1 & & 1 & \\
\hline \multicolumn{6}{|l|}{ Gender } \\
\hline - $\quad$ Male & 13.7 & $1.00(0.86-1.17)$ & 0.98 & & \\
\hline - Female & 14.9 & 1 & & & \\
\hline \multicolumn{6}{|l|}{ Education } \\
\hline - Low & 15.6 & $1.25(0.79-1.98)$ & 0.34 & $1.24(0.79-1.96)$ & 0.35 \\
\hline - Intermediate & 12.0 & $1.00(0.63-1.57)$ & 0.99 & $0.99(0.63-1.56)$ & 0.98 \\
\hline - High & 9.6 & 1 & & 1 & \\
\hline \multicolumn{6}{|l|}{ Occupation (main job) } \\
\hline - Not working & 14.9 & $1.10(0.81-1.48)$ & 0.55 & $1.10(0.81-1.48)$ & 0.56 \\
\hline - $\quad$ Study & 13.3 & $1.00(0.73-1.39)$ & 0.99 & $1.00(0.72-1.39)$ & 0.99 \\
\hline - Entrepreneur & 13.3 & $1.09(0.82-1.45)$ & 0.55 & $1.09(0.82-1.45)$ & 0.56 \\
\hline - $\quad$ Farmers/farm labores & 18.2 & $1.31(0.94-1.80)$ & 0.11 & $1.29(0.94-1.77)$ & 0.11 \\
\hline - $\quad$ Laborers & 13.1 & $1.12(0.81-1.55)$ & 0.49 & $1.12(0.81-1.55)$ & 0.48 \\
\hline - Others & 14.4 & $1.19(0.81-1.75)$ & 0.38 & $1.18(0.80-1.74)$ & 0.40 \\
\hline - Employee & 10.1 & 1 & & 1 & \\
\hline \multicolumn{6}{|l|}{ Socio-economic status } \\
\hline - Low & 14.8 & $1.11(0.94-1.31)$ & 0.23 & $1.10(0.93-1.31)$ & 0.25 \\
\hline - High & 12.3 & 1 & & 1.00 & \\
\hline \multicolumn{6}{|l|}{ Location of residence } \\
\hline - $\quad$ Rural & 15.5 & $0.97(0.84-1.13)$ & 0.74 & & \\
\hline - Urban & 13.1 & 1 & & & \\
\hline \multicolumn{6}{|l|}{ Area of residence (region) } \\
\hline - Sumatera & 15.5 & $1.19(1.01-1.40)$ & 0.04 & $1.18(1.00-1.39)$ & 0.05 \\
\hline - $\quad$ Eastern of Indonesia & 17.2 & $1.38(1.19-1.59)$ & 0.001 & $1.37(1.18-1.59)$ & 0.001 \\
\hline - Jawa-Bali & 12.5 & 1 & & 1 & \\
\hline \multicolumn{6}{|l|}{ Helmet use behavior } \\
\hline - Poor & 15.5 & $1.18(1.01-1.36)$ & 0.03 & $1.17(1.02-1.35)$ & 0.03 \\
\hline - $\quad$ Good & 12.1 & 1 & & 1 & \\
\hline \multicolumn{6}{|l|}{ Motorcyclist } \\
\hline - $\quad$ Yes & 12.9 & $0.81(0.47-1.39)$ & 0.44 & $0.75(0.63-0.89)$ & 0.001 \\
\hline - $\quad$ No & 19.0 & 1 & & 1 & \\
\hline \multicolumn{6}{|l|}{ Passenger of motorcycle } \\
\hline - Yes & 18.7 & $1.08(0.65-1.81)$ & 0.77 & & \\
\hline - $\quad$ No & 12.9 & 1 & & & \\
\hline \multicolumn{6}{|l|}{ Vision disfunction } \\
\hline - Yes & 40.6 & $3.85(2.06-7.17)$ & 0.001 & $3.52(1.97-6.29)$ & 0.0001 \\
\hline - $\mathrm{No}$ & 14.0 & 1 & & 1 & \\
\hline \multicolumn{6}{|l|}{ Loss of limbs } \\
\hline - $\quad$ Yes & 18.9 & $0.74(0.34-1.61)$ & 0.45 & & \\
\hline - $\quad$ No & 14.1 & 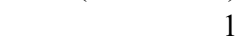 & & & \\
\hline \multicolumn{6}{|l|}{ Uncomfortable permanent scars } \\
\hline - $\quad$ Yes & 20.3 & $1.73(1.46-2.06)$ & 0.001 & $1.72(1.45-2.05)$ & 0.0001 \\
\hline - $\quad$ No & 13.1 & 1 & & 1 & \\
\hline
\end{tabular}


Respondents with poor helmet use behavior had a higher risk about 1.17 times to head injury due to traffic accidents than respondents with good helmet use behavior, and respondents who stayed in Sumatera and Eastern of Indonesia region had a risk of about 1.18 times and 1.37 times to head injury due to traffic accidents than respondents stayed in JavaBali region.

The respondent's role at the time of injury was one of the determinants of the traffic accident head injury with an adjusted OR of 0.75 ).

The sensory dysfunction and permanent scars that interfere with comfort, is related to traffic accident of head injury (Adjusted OR 3.52 and 1.72).

\section{DISCUSSION}

This analysis found that age is one of the determinants factors of helmet use behavior. In this study, the porportion of respondents in 5-14 years old group were the highest proportion to head injury due to traffic accident than others group. It is different from the 2018 Basic Health Research report that the high proportion of head injury in Indonesia was in the older age groups which were $64-74$ years old (16\%) and 75 years old and above $(17,1 \%)$ while in the age $5-14$ years group was only $11.4 \%$ and the lowest was in the 25-34 years and in the 15-24 years group $(8,7 \%$ and $9 \%) .^{3}$ A police department's report cited in a study on demographic transition and epidemiology 2019 showed most traffic accident victims in Indonesia were aged 15-19 years. ${ }^{22}$ Another study of traffic accidents during Eid Mubarak 2013 also showed a similar figure in the 15-24 years group. ${ }^{23}$

Different thing is happen in this analysis than the other two studies mentioned above as it, included younger age respondents that five years old and above and had specific data on head injury motorcyclist in traffic accidents, and helmet use behavor. The other two studies is learn about injuries of a traffic accident in common, not only focus about the head injury.

Negussie A, et all ${ }^{24}$ reported that $71.9 \%$ of 171 injured patients admitted to the hospital were causes by accidental injuries, mostly in $\leq 24$ years old group $(48.2 \%)$, and $51.4 \%$ causes by the road traffic accident injuries. Nevertheless, in terms of the impact of death, traffic accidents were included in the main causes of death for young people aged 15-29 years. ${ }^{25}$
In this research, only $44.4 \%$ of individuals had good helmet use behavior and were very low in the 5-14 age group (13.3\%). Christopher A German ${ }^{18}$ reported that teens and children were contributing to non-helmet use. Meanwhile, Michelle C. Fong ${ }^{26}$ reported that only $16.2 \%$ (out of 1632 ) motorcyclists observed were using helmets $(28.7 \%$ adults and $0.4 \%$ children). More motorcyclists (54.8\%) had never or only occasionally used helmets while riding.

The use of the helmet in Vietnam was better; more than $90 \%$ of adults and $30-50 \%$ of children used helmets. ${ }^{27}$ Similar to Vietnam, the majority of adult riders and pillions in Malaysia used helmets $(93.4 \%$ and $85.8 \%$ ), and only $30.5 \%$ of children used helmets. ${ }^{15}$ Observation in Thailand showed that $67 \%$ motorcyclists used helmets, while the proportion of adult motorcyclists wearing a helmet was 2.8 times higher than children. ${ }^{16}$

The differences between these studies might be due to different research methods. The 2018 Basic Health Research was a cross-sectional study and data on helmet use behavior was collected by interviewing respondents without observation, so the proportion obtained was relatively lower than other ASEAN countries except for Lao. -

A study in Lao by Michele showed a very low proportion of helmet use. It might be due to the motorcyclist's poor understanding of their country's regulation on motorcycle ridership and helmet use. Lao's law regulates a maximum of three person per in one motorcycle but the study observed 24 motorcycles $(2.8 \%)$ with four persons and 3 motorcycles $(0.4 \%)$ with five persons in each motorcycle. ${ }^{26}$

Limitation of this analysis was the lack information on respondent's attitude towards helmet use. Michele's study showed that most motorcyclists indicated that they did not like the feel of wearing helmets or their appearance when wearing helmets. It was also found that almost half of the motorcyclists did not have helmets for their children, or thought that their children were too young to use helmets. ${ }^{26}$

Alain Chichom-Mefire ${ }^{28}$ conducted a prospective cohort analysis of the characteristics and patterns of accident injuries in motorcyclist and passengers in urban areas, which found that almost all respondents did not use helmets. Drivers are more risky to suffer head and neck injuries than passengers. 
Motorcyclists and passengers had the same risk of lower leg injuries, because died in the emergency room were 3-4 \% and more riders died than passengers. Neck and head injuries were the main causes of death, serious injuries, and disability among motorcyclists. The use of helmets in motorcyclists can reduce almost $40 \%$ of deaths and reduced up to $70 \%$ risk of serious injury. $13,14,25$

The proportion of helmet use was higher in people with high socio-economic status than the low and medium status, because higher socio-economic status individu are more likely to buy a helmet. Unfortunately there was no further explanation related to the data source. Another study found that $29 \%$ of motocyclists said if they did not buy helmets for their children, because a helmets were too expensive or helmets were difficult to obtain. ${ }^{26}$

In Indonesia, motor vehicles of various types had increased from 2009 to 2012, particularly motorcycles by $13.11 \%$. There was $27 \%$ increase in the number of two-wheeled motorized vehicles in the world according to WHO data 2010 and $2013 .{ }^{25}$ Meanwhile, in high-income countries, the vehicles are increasing, but less than half of them have implemented minimum vehicle safety standards, while in middle-income countries where most vehicle manufacturers located, they do not implement those standards at all. ${ }^{25}$

Regulations on safe behavior on the road are important factors that can improve the behavior of road users, and will reduce road accidents. ${ }^{29}$ Changes in behavior of road users to a better way need to be supported by law enforcement and good understanding of the regulation itself. Helmet use behavior is one of the risk factors for road injuries besides vehicle speed, alcohol consumption, and others. This is shown by the positive impact of the regulation application from each risk factor which will reduce accidents, injuries, and deaths. ${ }^{29}$ Enforcement of effective regulations to increase helmet use will reduce head injuries. ${ }^{13}$

In conclusion, as many as $44.4 \%$ of individuals aged $\geq 5$ years old had good helmet use behavior, while Determinants of helmet use behavior were age, gender, education, occupation, socio-economic status, location of residence, and area of residence. As many as $14.1 \%$ of individuals suffered head injuries due to traffic accidents. Poor helmet use behavior was associated with an increase of 1.17 times head injury due to traffic accidents is compared to good behavior (adjusted OR 1.17; 95\% CI 1.02-1.35; p 0.03).

\section{Recommendation}

Necessary for tighter supervision from the police indirectly is a way to encourage both motorcycle riders and passengers to use helmets when riding, also motorcyclists should have riding licenses and be trained on how to ride safely before getting the license.

\section{Acknowledgements}

The authors gratefully acknowledge the Director General for the National Institute of Health Research and Development, dr. Siswanto, MHP; the Director of Center for Research and Development for Public Health Efforts, Ir. Doddy Izwardy, MA; and the Secretariat of the National Institute of Health Research and Development, Indonesian Ministry of Health for providing the opportunity to analyze the 2018 Riskesdas data. We also thank and give highest appreciation to Prof. dr. Emiliana Tjitra, M.Sc, Ph.D and dr. Iwan Ariawan, MSPH for their valuable inputs and suggestions to this manuscript.

\section{Author contribution}

The authors are LT, DD, NK, and LI with LT and DD as main contributor.

\section{Competing interest}

We declare that there is no competing interest in this study

\section{REFERENCES}

1. Ministry of Health. National Institute of Health Research and Development. Indonesia Basic Health Research (Riskesdas) Report 2007. Jakarta: Ministry of Health, National Institute of Health Research and Development; 2008.

2. Ministry of Health. National Institute of Health Research and Development. Indonesia Basic Health Research (Riskesdas) Report 2013. Jakarta: Ministry of Health, National Institute of Health Research and Development; 2014.

3. Ministry of Health. National Institute of Health Research and Development. Main Result of Indonesia Basic Health Research (Riskesdas) 2018. Jakarta: Ministry of Health, National Institute of Health Research and Development; 2018.

4. Ministry of Health. National Institute of Health Research and Development. Indonesia Basic Health Research (Riskesdas) 2018 Report. Jakarta: Ministry of Health, National Institute of Health Research and Development; 2019. 
5. Tana L, Ghani L. Determinant of injury among productive age workers in Indonesia. Bulletin of Health Research. Vol.43 No.3 September 2015.

6. Tana L. The contributing factors to injury's length of stay in hospital among productive age workers in Indonesia. Bulletin of Health System Research. vol.19, No.1, Januari 2016.

7. Badan Pusat Statistik. Kantor Kepolisian Republik Indonesia. 2013. [Cited 2015 Februari 24]. Available from http://www.bps.go.id/tab_sub/view. php?tabel $=1 \&$ id_subyek $=17 \&$ notab $=12$

8. Ae-Ngibise KA, Masanja H, Kellerman R, Agyei SO. Risk factors for injury mortality in rural Tanzania: a secondary data analysis[Internet\}. BMJ. 2012. [Cited 2015 March 5]. Available from: http://bmjopen.bmj. com/content/2/6/e001721.full

9. RAC Foundation. Mortality statistics and road traffic accidents in the UK[Internet]. NHS, 2011. [Cited 2015 February 10]. Available from http://www. racfoundation.org/assets/rac foundation/content/ downloadables $/ \mathrm{road} \% 20$ accident $\% 20$ casualty $\% 20$ comparisons $\% 20-\% 20$ box $\% 20-\% 20110511$.pdf)

10. Mehmandar M, Soori H, Amiri M, Norouzirad R, Khabzkhoob M. Risk factors for fatal and nonfatal road crashes in Iran. Iran Red Crescent Med J. 2014; 16(8): e10016.)

11. OECD/WHO (2012) Mortality from injuries. Health at a glance: Asia/Pacific 2012, OECD Publishing. [Cited 2015 March 31]. Available from http://dx.doi. org/10.1787/9789264183902-10-en

12. Sadeghi-Bazargani H, Samadirad B, HosseinpourFeizi H. Epidemiology of traffic fatalities among motorcycle users in East Azerbaijan, Iran. Biomed Res Int. 2018 Aug 19;2018:6971904. doi: 10.1155/2018/6971904. eCollection 2018.

13. Liu B, Ivers R, Norton R, Blows S, Lo SK. Helmets for preventing injury in motorcycle riders. Cochrane data Base Syst review. 2004; (2) CD004333. [Cited 2019 Juni 30]. Available from: https:/www.ncbi. nlm.nih.gov/pubmed/15106247

14. Nishi A, Singkham P, Takasaki Y, Ichikawa M, Chadbunchachai W, Shibuya K, et al. Motorcycle helmet use to reduce road traffic deaths in Thailand. Bull World Health Organ. 2018; 96(8): 514-514A DOI: 10.2471/BLT.18.215509 [Cited 2021 July 5]. Available from https:/www.ncbi.nlm.nih.gov/pmc/ articles/PMC6083397/

15. Oxley J, O’Hern S, Jamaludin A. An observational study of restraint and helmet wearing behaviour in Malaysia. Transportation Research Part F: Traffic Psychology and Behaviour. 2018; 176-184. [Cited 2021 July 5]. Available from https://doi. org/10.1016/j.trf.2018.03.028Get rights and content

16. Kumphong J, Satiennam T, Satiennam W. The determinants of motorcyclists helmet use: urban arterial road in Khon Kaen City, Thailand. J Safety Res. 2018;67: 93-97. DOI: 10.1016/j.jsr.2018.09.011
[Cited 2021 July 5]. Available from: https://pubmed. ncbi.nlm.nih.gov/30553434/

17. Setty NKH, Sukumar GM, Majgi SM, GoelAD, Sharma PP, Anand MB. Prevalence and factors associated with effective helmet use among motorcyclists in Mysuru City of Southern India. Environ Health Prev Med. 2020 Sep 4;25(1):47. DOI: 10.1186/s12199-020-00888-z. [Cited 2021 July 5]. Available from https://pubmed. ncbi.nlm.nih.gov/32887547/

18. German CA, Soontornmon K, Singkham P, Tanasugarn L, Thienmongkol $\mathrm{R}$, Weeranakin $\mathrm{N}$, et al. A systematic review on epidemiology and promotion of motorcycle helmet use in Thailand. Asia Pac J Public Health.2019 Jul;31(5):384-395. DOI: 10.1177/1010539519860733 [Cited 2021 July 5]. Available from: https://pubmed.ncbi.nlm.nih. gov/31431056/

19. Ramli R, Oxley J. Motorcycle helmet fixation status is more crucial than helmet type in providing protection to the head. Injury. $2016 \mathrm{Nov}$; 47(11):2442-2449. doi: 10.1016/j.injury.2016.09.022. Epub 2016 Sep 13

20. Kim S, Ro YS, Shin SD, Song KJ, Hong KJ, Jeong J. Preventive effects of motorcycle helmets on intracranial injury and mortality from severe road traffic injuries. Am J Emerg Med. 2018 Feb;36(2):173-178. doi: 10.1016/j. ajem.2017.07.044. Epub 2017 Jul 15.

21. Ministry of Health. National Institute of Health Research and Development. Guidelines for Filling in the Questionnaire Indonesia Basic Health Research (Riskesdas). 2018. Jakarta: Ministry of Health, National Institute of Health Research and Development; 2018.

22. Setyonaluri D, Aninditya F. The study in health sector, demographic transition and epidemiology. Directorate of Public Health and Nutrition, Deputy of Human Development, Community and Culture Ministry of National Development Planning/National Development Planning Agency. 2019;35-6.

23. Halim FXS. Study of traffic accident during EID Mubarak. 2013. National Institute of Health Research and Development. 2014;41.

24. Negussie A, Getie A, Manaye E, Tekle T. Prevalence and outcome of injury in patients visiting the emergency Department of Yirgalem General Hospital, Southern Ethiopia. BMC Emerg Med. 2018 May 22;18(1):14. doi: 10.1186/s12873-018-0165-6. [Cited 2019 October 20] Available from https://www. ncbi.nlm.nih.gov/pubmed/29788913

25. World Health Organization. Global Status Report on Road Safety 2015. [Cited 2019 October 20]. Available from http://www.ansr.pt/SegurancaRodoviaria/ Internacional/Documents/Global\%20Status $\% 20$ Report\%20On\%20Road\%20Safety\%202015.pdf

26. Fong MC, Measelle JR, Dwyer JL, Taylor YK, Mobasser A, Strong TM, et al. Rates of motorcycle helmet use and reasons for non-use among adults and children in Luang Prabang, Lao People's Democratic Republic. BMC Public Health (2015) 15:970. DOI 
10.1186/s12889-015-2304-2. [Cited 2019 October 22]. Available from https://bmcpublichealth.biomedcentral. com/articles/10.1186/s12889-015-2304-2

27. Pervin A, Passmore J, Sidik M, McKinley T, Tu $\mathrm{H}$, Thi N, et al. VietNam's mandatory motorcycle helmet law and its impact on children. Bull World Health Organ. 2009;87:369-73. [Cited 2019 October 20]. Available from https://www.who.int/bulletin/ volumes/87/5/08-057109/en/

28. Chichom-Mefire A, Atashili J, Tsiagadigui JG, FonAwah C, Ngowe-Ngowe M. A prospective pilot cohort analysis of crashcharacteristics and pattern of injuries in riders and pillion passengers involved in motorcycle crashes in an urban area in Cameroon: lessons for prevention. BMC Public Health (2015) 15:915 DOI 10.1186/s12889-015-2290-4 [Cited 2019 October 20]. Available from https://bmcpublichealth.biomedcentral. com/articles/10.1186/s12889-015-2290-4

29. Peden $M$ et al., editors. World report on road traffic injury prevention. Geneva, World Health Organization, 2004 in World Health Organization. Global Status Report on Road Safety 2015. [Cited 2019 October 22]. Available from

http://www.ansr.pt/SegurancaRodoviaria/ Internacional/Documents/Global\%20Status $\% 20$ Report\%20On\%20Road\%20Safety\%202015.pdf 